\title{
A conceptual framework for the integral management of marine protected areas
}

\author{
Celia Ojeda-Martínez ${ }^{\mathrm{a}, *}$, Francisca Giménez Casalduero ${ }^{a}$, Just T. Bayle-Sempere ${ }^{\mathrm{a}}$, \\ Carmen Barbera Cebrián ${ }^{\mathrm{a}}$, Carlos Valle ${ }^{\mathrm{a}}$, Jose Luis Sanchez-Lizaso ${ }^{\mathrm{a}}$, Aitor Forcada ${ }^{\mathrm{a}}$, \\ Pablo Sanchez-Jerez ${ }^{\mathrm{a}}$, Pablo Martín-Sosa ${ }^{\mathrm{b}}$, Jesús M. Falcón ${ }^{\mathrm{b}, \mathrm{c}}$, Fuensanta Salas ${ }^{\mathrm{d}}$, Mariagrazia Graziano ${ }^{\mathrm{e}}$, \\ Renato Chemello ${ }^{\mathrm{e}}$, Ben Stobart ${ }^{\mathrm{f}}$, Pedro Cartagena ${ }^{\mathrm{a}}$, Angel Pérez-Ruzafa ${ }^{\mathrm{d}}$, Fréderic Vandeperre ${ }^{\mathrm{g}}$, \\ Elisabeth Rochel ${ }^{\mathrm{h}}$, Serge Planes ${ }^{\mathrm{h}}$, Alberto Brito ${ }^{\mathrm{c}}$ \\ ${ }^{a}$ Department of Marine Sciences and Applied Biology, University of Alicante, P.O. Box 99, E-03080, Alicante, Spain \\ ${ }^{\mathrm{b}}$ Centro Oceanográfico de Canarias, Instituto Español de Oceanografia. Ed. Sanahuja, Avda. 3 de Mayo 73, 38005 S/C Tenerife, Canary Islands, Spain

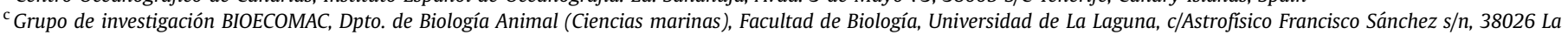 \\ Laguna, Santa Cruz de Tenerife, Canary Islands, Spain \\ ${ }^{\mathrm{d}}$ Department of Ecology and Hydrology, Faculty of Biology, University of Murcia, 30100, Murcia, Spain \\ e Dipartimento di Ecologia, Laboratorio di Conservazione della Natura, via Archirafi 28, 90123 Palermo, Italy \\ ${ }^{\mathrm{f}}$ Centro Oceanográfico de Baleares, Instituto Español de Oceanografia, Muelle Poniente s/n, Palma de Mallorca, Spain \\ ${ }^{g}$ Department of Oceanography and Fisheries, University of the Azores, PT-9901-862 Horta, Portugal \\ ${ }^{\mathrm{h}}$ UMR 5244 EPHE CNRS UPVD, Centre de Biologie et d'Ecologie Tropicale et Méditerranéenne, Universite de Perpignan, 52, Av. Paul Alduy, 66860 Perpignan, France
}

\begin{abstract}
A B S T R A C T
A general conceptual framework for the management of marine protected areas (MPAs) was developed. The driver-pressure-state-impacts-response (DPSIR) framework was used to determine the elements affecting MPAs. The developed evaluation framework helped to select an appropriate suite of indicators to support an ecosystem approach, an assessment of the MPAs functioning and policy decisions. Gaps derived from the management and policy responses in the MPAs were also outlined. It was concluded that the DPSIR framework can help to simplify the complexity of MPA management. This document is a tool for policy makers, scientists and general public on the relevance of indicators to monitor changes and MPAs management.
\end{abstract}

(c) 2008 Elsevier Ltd. All rights reserved.

\section{Introduction}

The marine system is arguably more complex than any other ecosystem with highly interrelated processes between its physical, chemical and biological components. Its study and management requires information on all processes and an understanding of the structure and function of the systems. In addition, the increasing amount of national, supra-national and global legislation and agreements, is producing the necessity to develop tools for the sustainable use of the marine environment, in particular management for conservation and biodiversity in order to protect habitat integrity. This calls for multi-disciplinary approaches to marine protected areas research and resource management.

From the First World Conference on National Parks, when countries were invited to create marine protected areas and parks, the number of MPAs and surface protected has increased [1]. The spatial extent of marine areas protected globally has grown at an

\footnotetext{
* Corresponding author. Tel.: +34965903400x2916; fax: +34965903815.

E-mail address: celia.ojeda@ua.es (C. Ojeda-Martínez).
}

annual growth rate of $5.2 \%$, over the last two decades, which have been established with different aims. Approximately 2.2 million $\mathrm{km}^{2}$, equivalent to $0.6 \%$ of the world's oceans and $1.5 \%$ of the total marine area under national jurisdiction, are currently protected [2]. In general, MPAs have been proposed throughout the world as an optimal way to protect marine ecosystems [3-5]. The effectiveness of a MPA, among other many things, is related with its management. This should include defined objectives and goals from the outset, site selection, zoning, planning and implementing a surveillance and enforcement system, as well as monitoring actions [6]. In order to determine the validity of MPAs as fisheries management tools is essential to evaluate the MPA performance by means of continuous monitoring.

Indicators are increasingly being developed and used as management tools to address environmental issues [7-10], they are also used to assess the effectiveness of the actions and policies implemented, by measuring progress towards environmental targets $[8,11]$. In this sense indicators can contribute in the monitoring of the effectiveness of MPAs. Indicators are variables used to quantify or qualitatively describe phenomena that are not directly easily measured, but which society considers valuable to monitor 
over time $[12,13]$. The paradox is that while the scientific community is mostly working on very detailed and narrower aspects the managers require a holistic and ecosystem approach, not necessarily at a very high level of detail [14]. The selection of a set of indicators must provide information that can be clearly understood by managers and stakeholders, providing them with a base for decision making.

However before selecting and choosing indicators it is necessary to clearly define cause-effect relationships, and to establish a framework from which the indicators can be selected. One of the techniques available in defining indicators is the driver-pressurestate-impact-response (DPSIR) conceptual framework, initially developed by the OECD (Organisation for Economic Co-operation and Development). The DPSIR scheme of indicators is a flexible framework that can be adapted to the necessities of specific programmes to stress the different indicator types. It has been widely used for different purposes, for the implementation of the European Water Framework Directive [15-17], coastal zone studies $[10,18-26]$ and in fisheries management [14]. This methodology works well at simplifying the complexity of environmental management and makes easier communication among policy makers, scientists and the general public, improving the cooperation among them. It allows a better understanding between the results from an action developed and the effects produced in the different system components (e.g. the fisheries, the socioeconomics).

\subsection{Problems facing MPAs management}

Many calls have become for the further designation of MPAs, understanding as an MPA as those that present conservation as resource protection objectives, included all the categories defined by the IUCN [27], recommending that $20-30 \%$ of the area of each marine habitat should be designated as no-take area by 2012 [28]. MPAs reflect the extension of scientific and ethical concerns for the wider health of marine ecosystem conservation, including their component populations and habitats, the processes that sustain them and the functions they provide, having beneficial effects for habitat-specific species associated with sensitive grounds [29] or very sedentary species [30]. However, many authors argue that MPAs are not a fishery panacea [31] basically because few data sustain positively their potential to promote sustainable fish stock yields. Nevertheless these authors are not referring to multiple-use zones, but huge areas with some kind of management [32].

In general MPAs have been sited at intrinsically ecological rich places based more on opportunistic human factors than on relevant ecological and/or socioeconomic features such as: currents structure, habitat requirements, inter-specific processes, fishing effort distribution, effects of MPA location, size and design [33], resulting in a very heterogeneous pool of small reserves along the coast and a number of very large high seas reserves within the EEZs countries. This heterogeneity is also reflected in the management implemented and, therefore, in its results, being difficult postcomparisons to deduce general trends derived from the effects of protection. Moreover, many of the objectives assigned to MPAs have not been tackled, resulting in a very narrow use of methodological approaches and study subjects (Ojeda-Martinez, unpublished data). Another problem facing MPAs management is the lack of coordination at different levels. Although some authors advocated [34] or interpreted [35] this increase of MPAs as a network in some regional areas (e.g. the Mediterranean Sea), the fact is that they are not working like it. There lacks a minimum of coordination on their functioning, even among MPAs depending on the same institution. Furthermore, fewer than 10\% of MPAs that exist today achieve their management goals and objectives [2,13], and in many cases, the effects resulting from the protection are not duly disseminated, creating uneasiness in many stakeholders and users. Furthermore, there are few studies and mainly located in some areas that analyse management by itself, relating the investment (in terms of budget, staff, time of surveillance, etc) in the MPA with those elements that theoretically should be affected by the protection $[13,36]$. Therefore MPAs management needs to look towards an integrated governance approach that recognizes the interdependences of the different elements, and the need to know and manage the effects of each activity affecting the MPA. With typical small MPAs the activities and management of the surrounding and upstream areas are major factors and if these including particularly their impacts and sustainability in relation to the designated area - are not studied, the prospect of integration is remote.

The purpose of this document was to identify, define and discuss the ecological, socioeconomic and related essential variables that can potentially be used as indicators, in order to assess the effectiveness of MPAs as a policy response to conserve and restore fisheries and marine biodiversity. The specific goals include: a) to select the main components of the marine biodiversity affected by fisheries and tourism, including their descriptors and their derived consequences; b) to define a conceptual framework relating the selected components; c) to propose a set of variables that can potentially be used as indicators at each level in the DPSIR framework.

\section{Methodological approach}

\subsection{Establishment of an expert panel}

The methodological approach of this research started with the establishment of an expert panel formed by scientists belonging to EMPAFISH project (http://www.um.es/empafish/). This group was formed by experts in: fisheries, MPAs, marine ecology, mathematics, statistics and multi-criteria analysis. The expert panel, such as those proposed for other purposes $[5,37,38]$ was formed by a principal committee which led the process. This principal committee analysed different methodological approaches and selected the DPSIR framework, among all of them. The main objective of the expert panel was to define a conceptual framework which improved the understanding of the complexity of linkages and feedbacks between the causes and effects within environmental issues in MPAs. Also look for management gaps and identify variables as potential indicators, with the help of the conceptual framework defined. This process lasted about eleven months, weekly meetings were held by the expert panel, while more frequent ones, were held by the principal committee, until the development of the conceptual framework and the indicators definition.

\subsection{Participation process}

The first step of the participation process (Fig. 1) was to define the key elements that are those components of the ecosystem that are susceptible to be affected by any of the elements generated by human activity, particularly from fishing and tourism as the main driving forces affecting the environment. As the objectives of the project were to assess the effectiveness of MPAs as management tools, the responses on the framework were defined as the actions arising from the existence of such figures of protection. Causeeffect diagrams were developed and were broken down into the different elements within the DPSIR framework. Each element was studied in detail, based on the experience of the expert panel and on a deep search in the bibliography, including every cause or factor that interacted with the element. Identification according to the DPSIR framework was done to establish at which level of the 


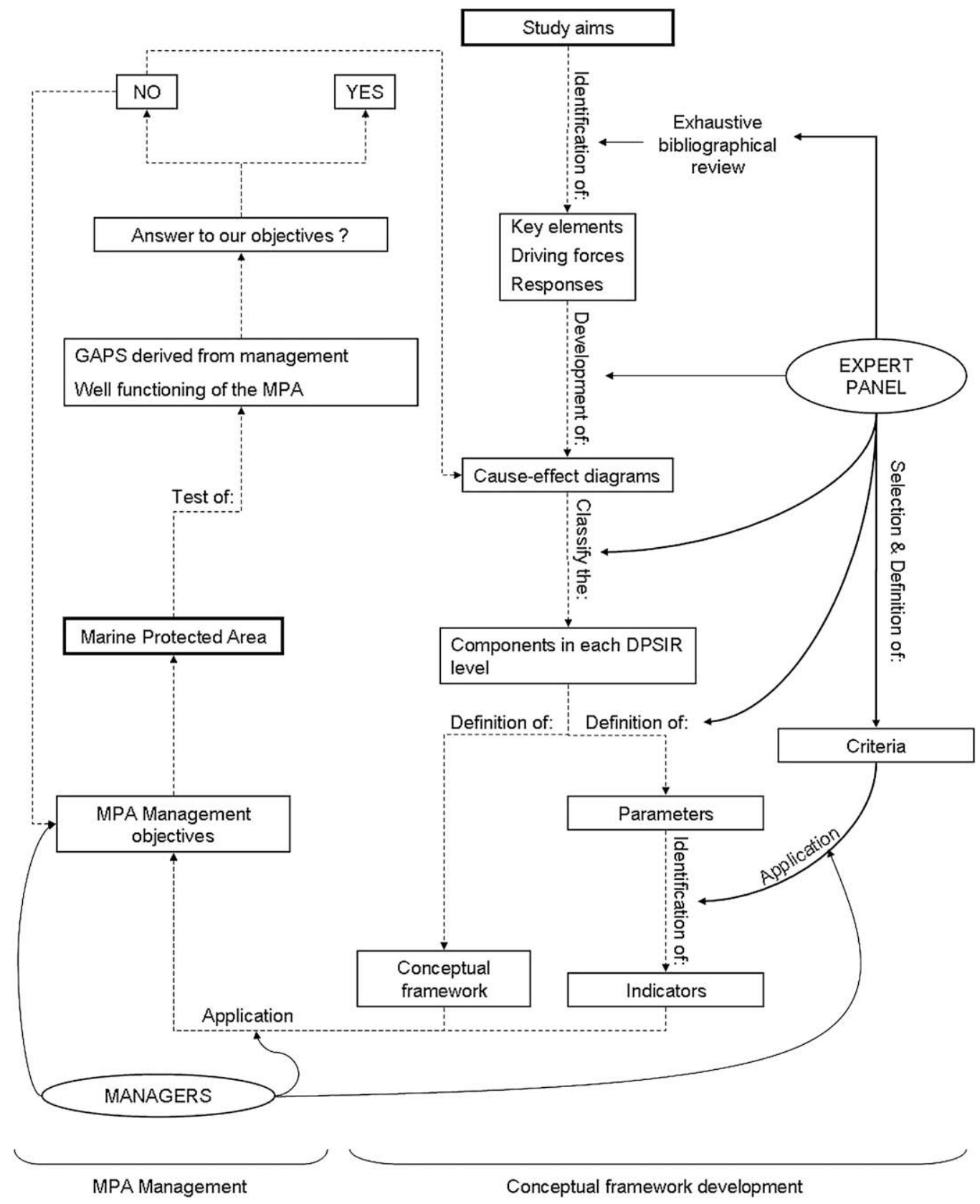

Fig. 1. Scheme of the participation process to develop the DPSIR conceptual framework and its application to the management of a marine protected area.

framework the elements were found (driving forces, pressures, states or impacts). Every management action associated with MPAs was identified and broken down into different parts, introducing them in the conceptual framework and connecting as responses to the driving forces, pressures, states or impacts. In this phase gaps in the overall responses of the MPAs management were identified towards the different levels of the framework. The search for all possible indicators associated with each element of the model was the next step.

\section{MPAs DPSIR framework}

The first results were the definition and selection of the key elements, the driving forces and the responses. Key elements were defined as those components of the ecosystem that are susceptible to be affected by any of the elements of the DPSIR framework. They play an important role in the DPSIR framework, as cause-effect diagrams are based on the relationships between these elements and the system studied. The key elements selection is an important part of the framework and managers are mostly interested, in them, as they need to define effective actions in prevention, restoration and control. For the general conceptual framework, the key elements selected were; species and habitats protected by European directives (Habitats Directive, Barcelona Protocol concerning Specially Protected Areas and Biodiversity in the Mediterranean, OSPAR Convention and those featured in the IUCN red list); target commercial species; ecological process developed (e.g. recruitment, biological production, species interaction, genes transference) and socioeconomic processes (e.g. incomes, socioeconomic resources, demography). Fishing and tourism sectors were chosen as driving forces. Driving forces: are understood as the factors that cause changes in the system; they can be 


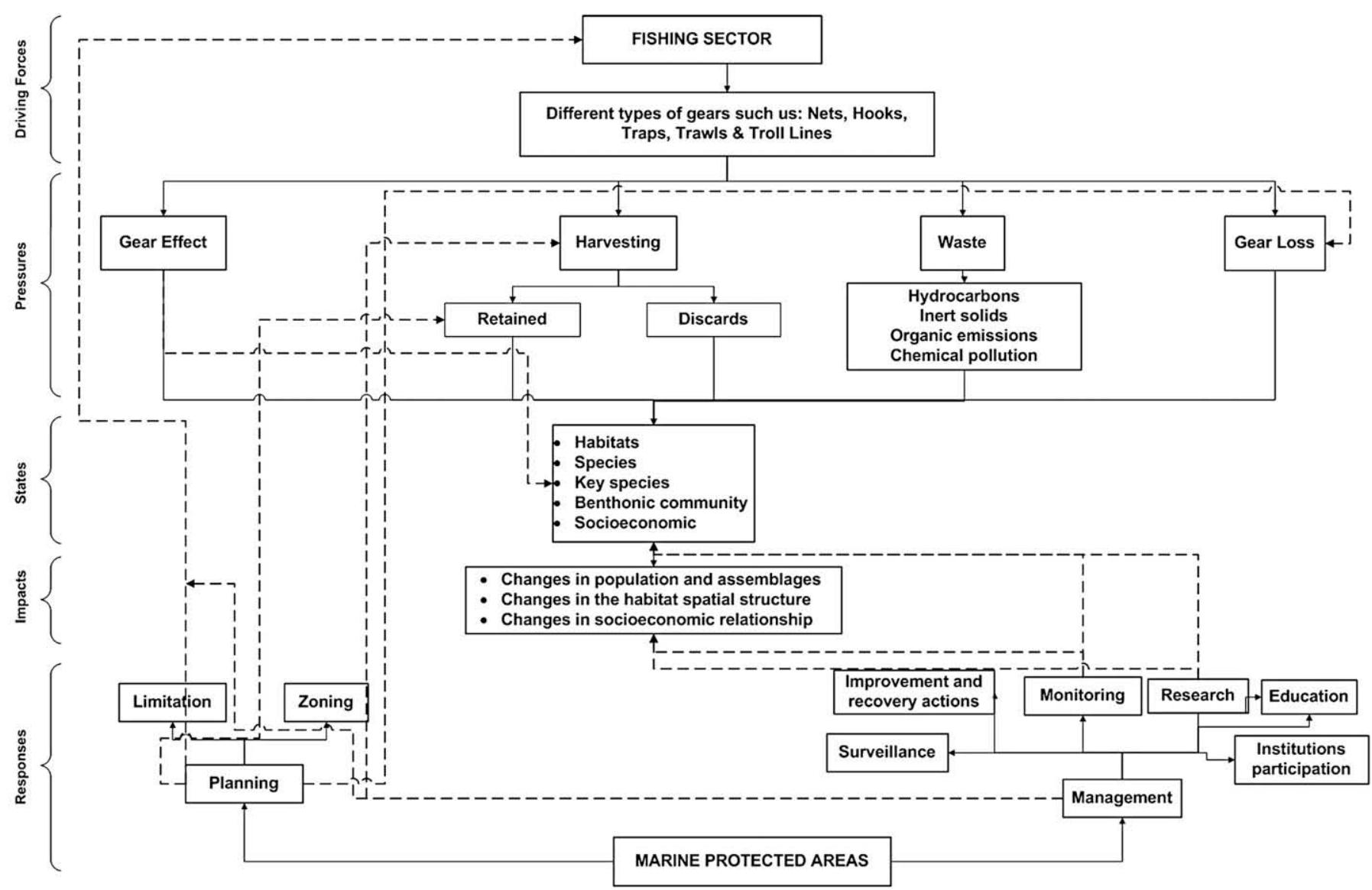

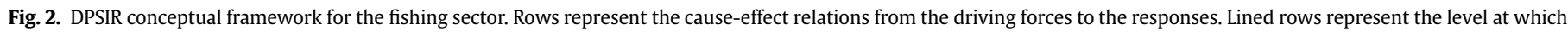
responses can act.

social, economical or ecological and can have positive or negative influences on pressures. These economical areas were chosen as they are mainly the sectors that generate activities affecting most MPAs in developed countries, although this can be different in underdeveloped countries [14]. Responses: that are the efforts made by society as a result of the changes manifested, can be any legal measure that is done to manage the marine environment as e.g. fishing gears banned and artificial reef installation. Because of the objectives in the conceptual framework, the responses were the MPAs, as indicators and gaps for MPAs present and future management must be found. In order to make policy recommendations for the management of MPAs and the selection of indicators, it is first necessary to describe the present state of the marine environment, its pressures and its management. Once the links between driving forces, pressures (that are the human activities that directly affect the system), states (are the condition of the system at a specific time and is represented by a set of descriptors of system attributes that are affected by pressures) and impacts (that are the effects on human health and/or ecosystems) are clear, policy responses can be formulated.

\subsection{The fishing sector as driving force: pressures, states and impacts}

Fishing incorporates different types of fishing gears and therefore the fishing sector driving force has been divided into subdriving forces, taking into account the different fishing gears (Fig. 2). Depending on the type of fishing gears used, the fishing activities affect the marine environment in different ways. Each sub-driving force embraces the different types of fishing using the different gears considered. The number of fishing boats/year can be a good example of a driving force parameter as it reflects the fishing activity round MPAs (Fig. 3). Several actions contribute to generate pressures on the system, the pressures were chosen as they affected our key elements. The different fishing gears cause similar pressures over the key elements and the states, its measure is what makes pressures different. Fishing has an environmental effect on many coastal areas [34,39] and it can exert pressure over the marine environment in a number of different ways: i) Extraction or harvesting on the resource at a higher rate than its capacity to regenerate is the most direct pressure (e.g. the sighting of professional fishing activities/year (Fig. 3), reflects the pressure exerted in the MPA boundaries or close to them, being a good indicators). This is not only unsustainable in economic terms, but also has significant effects elsewhere in the ecosystem. Generally, impacts are the causes that evoke responses and fishing activities usually cause a decrease in the abundance, biomass and size of commercial and non-commercial species [34,40-43], the measure of these parameters being a good indicator (e.g. species biomass as a state indicator (Fig. 4) and big Sparidae biomass as an impact indicator (Fig. 5). As the target species declines due to over fishing, others became more dominant and the whole structure of the ecosystem and typically the fishery targets altered. Stocks are over exploited so there is a decrease in total catch of the initial high trophic level target species, but as in the case of some low trophic level target species, fishing down the food chain can for a time increase total catch. ii) The effect of fishing gear on the non-target species, communities and habitats (e.g. total or partial broken of species like Pinna nobilis or coral species, and discards), that produces substantial habitat destruction by trawl and dredge gears on first use and destruction of the seabed ecosystem with little recovery in 


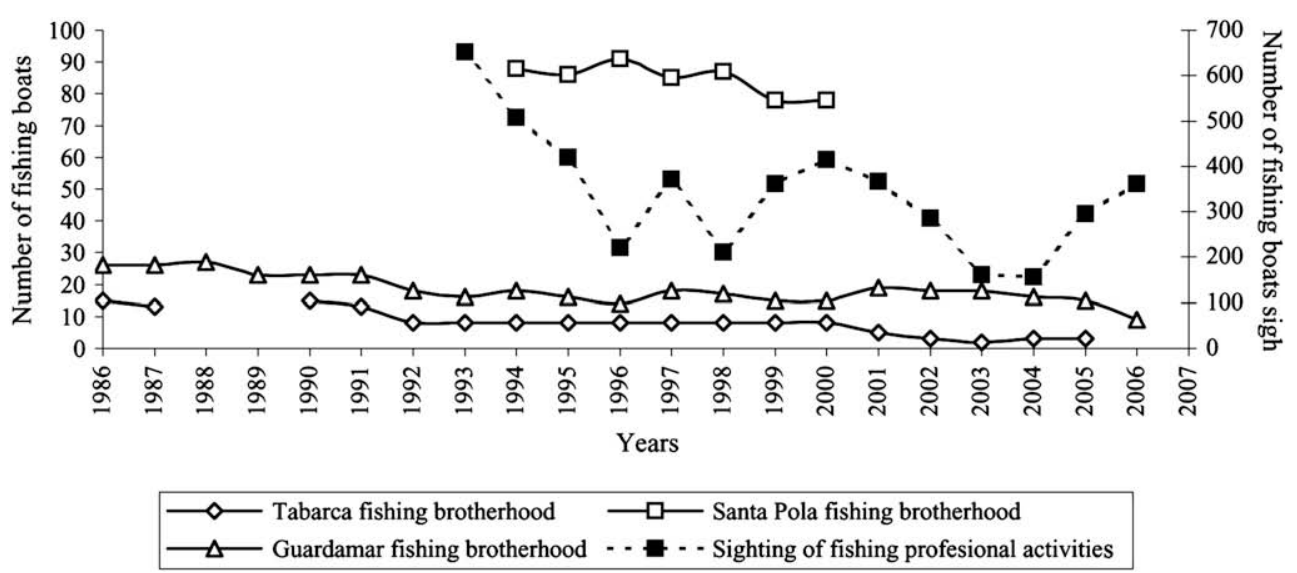

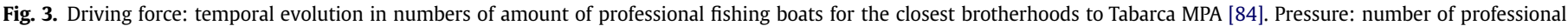
fishing activities close to the MPA, obtained by the Tabarca MPA surveillance. Data source: Tabarca MPA surveillance technical reports (TRAGSA, Secretaría de Pesca Marítima).

regularly trawled or dredged areas. Discards attract and increase the number of scavenger fish [44], invertebrates and seabirds [45], varying the relationships among ecosystem components. Depending on the type of gear used, the effect on species and habitats modifies the spatial structure in different ways. Other less aggressive gear, e.g. trammel nets, may also affect the target and nontarget species, thus modifying the population structures. Some static fishing tackles do not exert this type of pressure [46-48]. iii) Waste, understood as detritus generated by the stakeholders, litter dropped from the deck, hydrocarbon emissions by boats, organic emissions and chemical pollution, is an indirect pressure produced by the fishing sector. Pollution although not an objective of fishing is a direct consequent operational pressure on the habitats and species affected. The major impact of inert solids waste is the mortality of species such as turtles that mistake plastics and other rubbish as jellyfish and ingest them. Hydrocarbons are also a problem as they are deposited on sessile and pelagic species, as well as birds. In the case of coral reefs and some sediment studies it has been shown that hydrocarbons can have long-term persistent effects killing invertebrates and inhibiting settlement of larvae to replace adults that have died. Inert solids are a problem for filterfeeding species whose filtering appendages can become obstructed resulting in death. Most species and habitats are buried by inert solids and hydrocarbons, killing them or limiting their vital functions, such as photosynthesis. iv) Lost tackles are also a hazard and dangerous to wildlife (fishes, marine mammals, turtles and birds).
Lost gears may affect habitats, but in most cases they affect species, key species like turtles and sea mammals [49], can be totally or partially broken or trapped by them. Birds are also affected by lost gears, suffering amputations of wings and feet [50]. As animals are trapped, they die, which increases the scavenger presence modifying the inter-specific relations.

\subsection{The tourism sector as a driving force: pressures, states and impacts}

Ocean and coastal tourism is widely regarded as one of the fastest growing sectors of contemporary tourism [51], indeed tourism is the driving economic sector (Fig. 6) in many coastal zone areas because it is seen as a cost effective means of bringing development and foreign currency earning capacity to isolated areas and countries. Tourism is expected to continue to grow, and nowadays is producing a major environmental impact on many coastal areas. Nevertheless, the popularity of fishing, surfing, scuba diving, windsurfing, whale watching and yachting and selling of "sun, sand and surf experience", drives the development of beach resorts and associated residential and commercial infrastructure (e.g. this driving force can be measured by the indicator of the evolution of the number of diving permissions in an MPA (Fig. 7). This brings increased pressure space and resource competition on coastal areas which may already be subject to highly concentrated use and infrastructure stress through agriculture, human

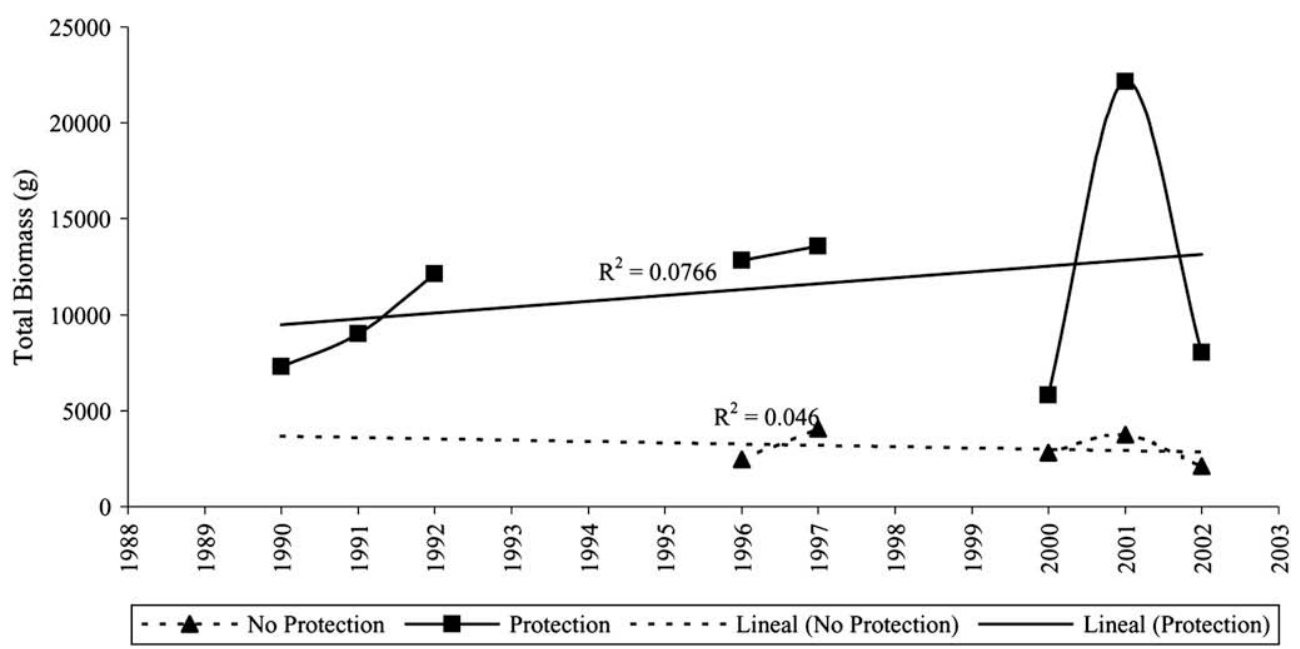

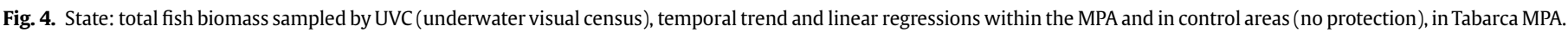




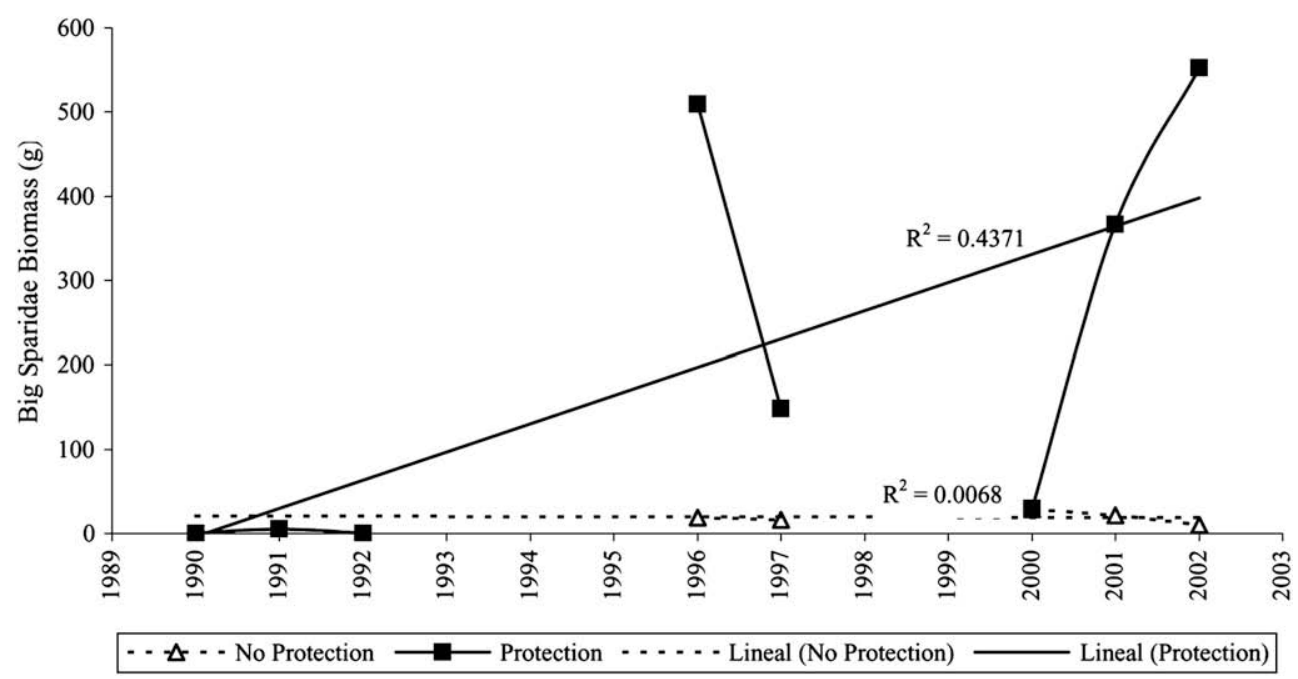

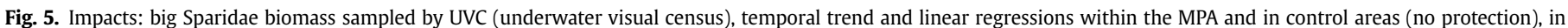
Tabarca MPA.

settlements, fishing, urban, industrial transport and communications development [51]. Also this increases a whole of social and cultural impacts, derived from the abandonment of traditional economic activities, to adapt to new patterns of behaviour, use and consumption of resources and management of wastes [52]. Pressures of marine tourism can be broadly categorised as ecological, social and cultural: i) Angling from shore, angling from boat and spear fishing are very popular activities in most countries where they are practiced at recreational and competitive levels [43,5355]. These activities are forbidden in most of the marine protected areas, but are allowed along the coast. However, there are still certain problems, such as the illegal selling of the catches or the resistance of spear fishermen to comply with protection measures, despite spear fishing could be policed and possession of spear fishing equipment could be a controlled activity. Although spear fishing is usually carried out at low intensity along all suitable

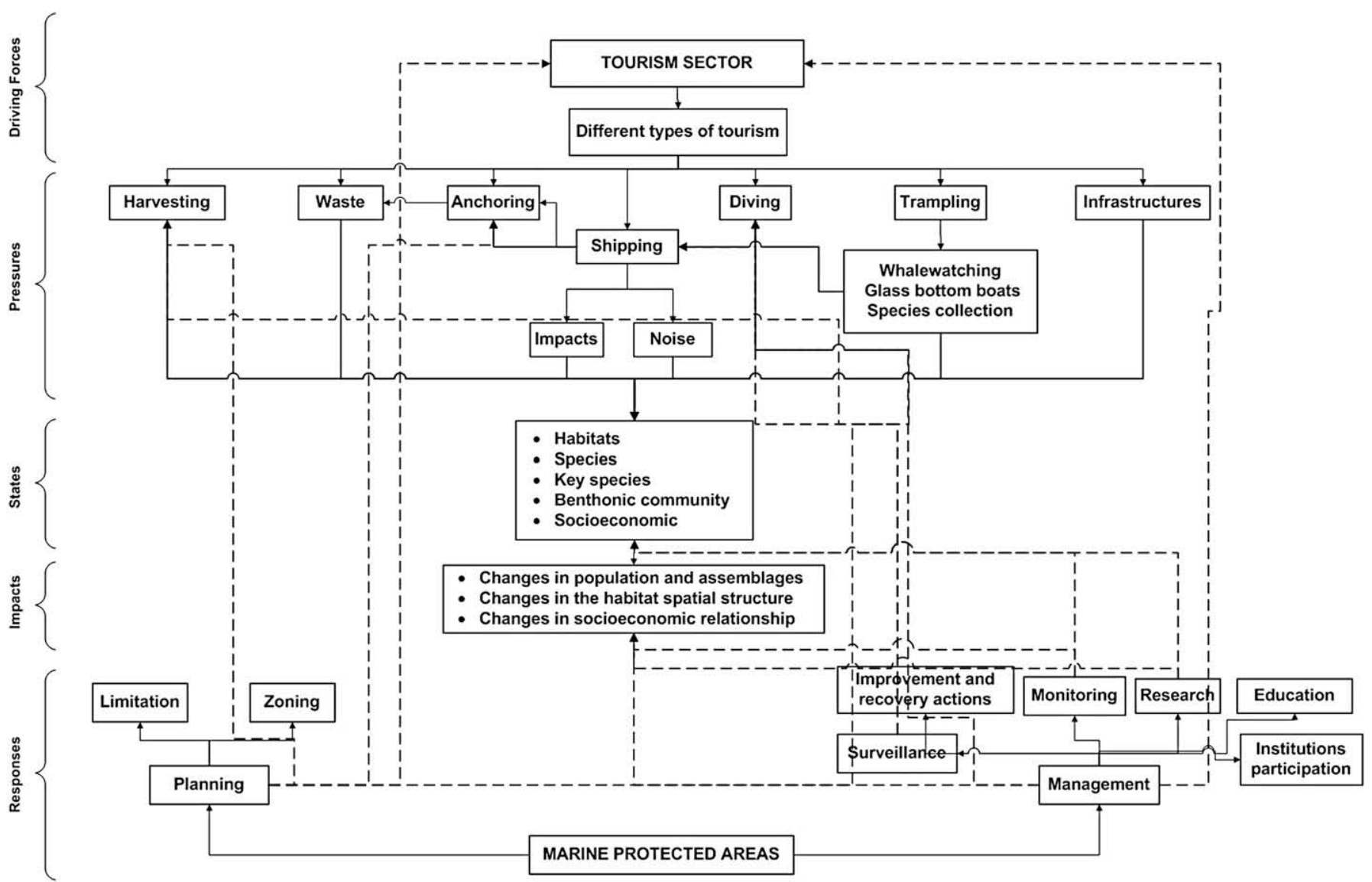

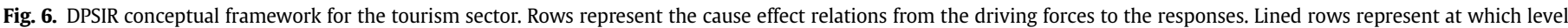
can act the responses. 


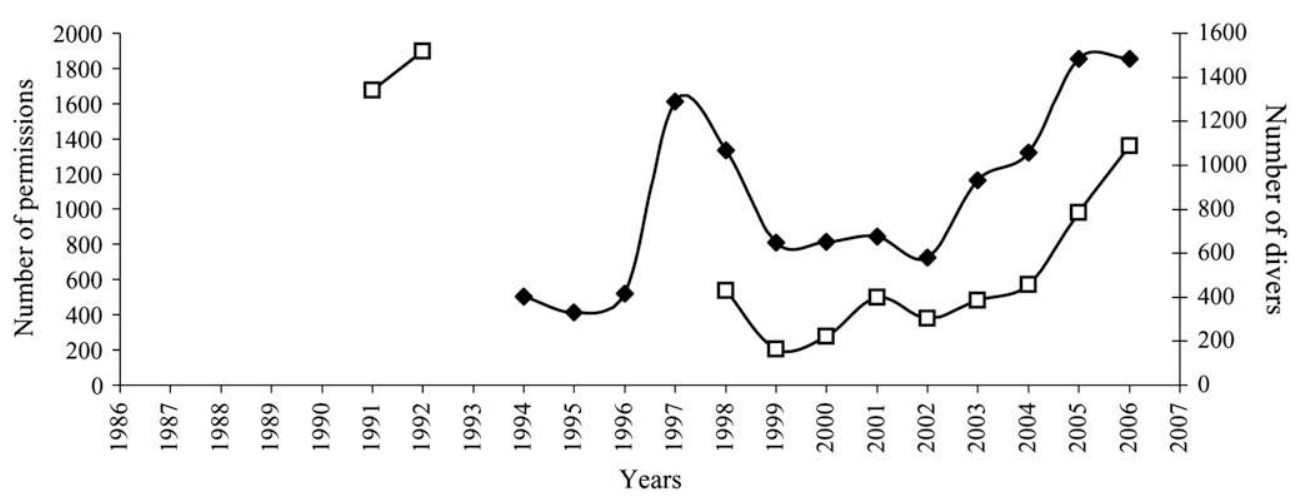

$\longrightarrow$ Total diving permissions $\rightarrow \square-$ Total number of divers

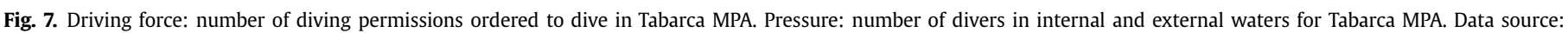
Tabarca MPA surveillance technical reports (TRAGSA, Secretaría de Pesca Marítima).

stretches of coast, (except during competition events), there is published evidence that, in the western Mediterranean, spear fishing can affect the composition of fish communities [56-59] and the structure of fish populations [60-62]. Conflicts between different user groups can arise because recreational fishing may take place in areas closed to commercial fishers and they may compete for the same resources. ii) Diving and snorkelling have been well studied overseas [63] and this pressure also generates most of the incomes of coastal areas e.g. the real number of divers in the MPA is an indicator to assess the pressure of this driving force (Fig. 7). A percentage of divers who swim too close of the bottom may break species [64]. Fragile branching corals are the most susceptible to breakage [65], bryozoans and sea fans have erosion problems due to this pressure [66]. Some studies on snorkellers have detected larger numbers of broken species in areas actively used by snorkellers, including snorkel trails, but the level of breakage levelled off quickly [65]. Other associated effects are changes in fish behaviour due to feeding [67]. iii) Tourism produces problems due to trampling [68-70] and illegal species collection in accessible rocky shore areas. It can provoke the replacement of low growth (e.g. Cystoseira spp) to rapid growth opportunistic species. Visitors usually collect key species which inserts pressure similar to the extraction done by recreational fishing. Furthermore, indirect effects include: erosion by trampling, gradual changes in vegetation structure and plant species composition as an adaptation to mechanical pressure. iv) Also visitors, divers, shipping and recreational fishing, generate waste in many other different ways, as happened in the fishing sector. v) Visitors need to have infrastructure built and they create a seasonal demand for resources [71]. In some cases, this expansion generates a need of complementary infrastructures (e.g. desalination plants, sewage plants, etc) to provide this demand (e.g. fresh water necessities in Mediterranean localities doubles during the tourist season incrementing subsequently the amount of sewage processing, that at the end is more important for near shore water, so does the amount of sewage processed [71]). Besides land-use, demand for resources and need for waste disposal facilities cause pressure on fresh water and natural coastal habitats. Uncontrolled development associated with tourism affects coastal ecology (e.g. varying the ecological balance through eutrophication, if adequate standards of design and implementation of sewage management are not adopted). Construction in coastal regions, sand erosion and instabilities in beaches, have destructive effects on fauna, flora and habitats and, in particular, on endemic species [72]. vi) Anchoring and mooring generate impacts associated with other pressures such as recreational fishing, shipping and diving and have been well studied [73]. A series of extensive impact assessments have found that pressures of moorings on the surrounding areas are minimal, apart from the 'footprint' under the moorings. Anchoring of both tourist and recreational boats is a significant issue in heavily visited sites [74]. Anchors and anchor chains are capable of breaking multiple species (e.g. coral colonies) at each drop and affect habitats like Posidonia oceanica meadows.

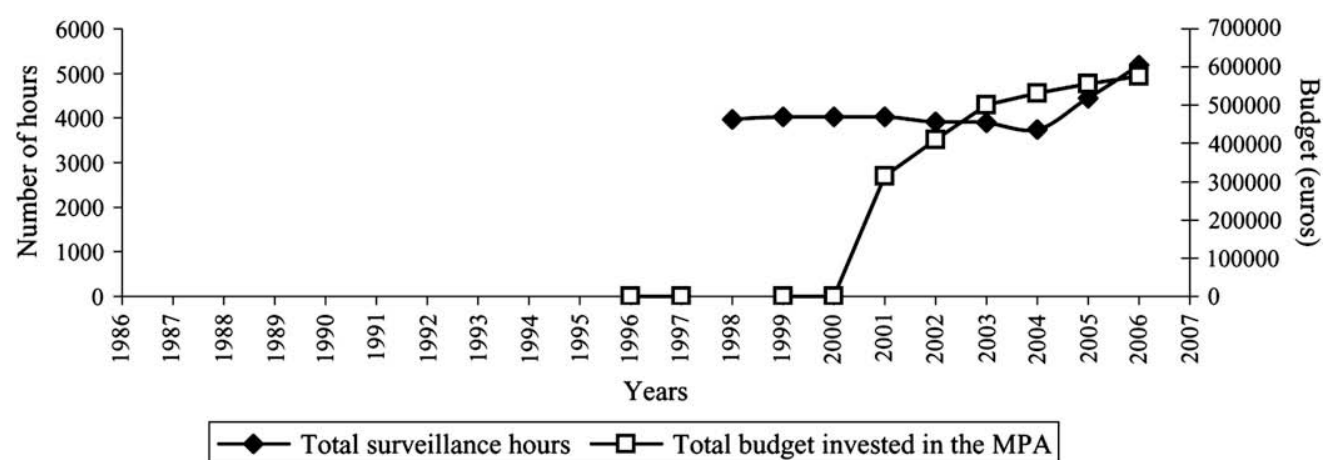

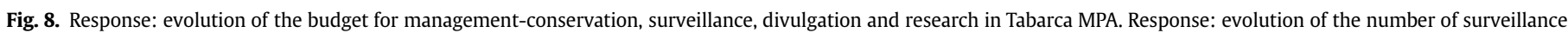

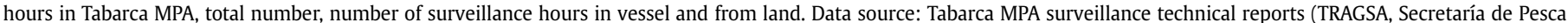
Marítima). 
Table 1

List of potential indicators with their definition, developed from the DPSIR conceptual framework.

\begin{tabular}{|c|c|c|c|}
\hline Type & Sector & Indicator & Definition \\
\hline \multirow[t]{25}{*}{$\begin{array}{l}\text { Driving } \\
\text { forces }\end{array}$} & Fishing & Number of fishing boats & $\begin{array}{l}\text { Temporal and/or spatial variations in the number of the professional fishing boats that fish on the Marine } \\
\text { Protected Area (MPA) or its boundaries. }\end{array}$ \\
\hline & Fishing & Number of fishers & $\begin{array}{l}\text { Temporal variations on the number of the people working for the fishing sector or industry. Principally } \\
\text { people fishing. }\end{array}$ \\
\hline & Fishing & Fishing sector profit & $\begin{array}{l}\text { Temporal variations of the profit of the fishing sector. Differences of the profit of this sector with the } \\
\text { establishment of the MPA. }\end{array}$ \\
\hline & $\begin{array}{l}\text { Fishing \& } \\
\text { tourism }\end{array}$ & GDP produced by the sector & Temporal distribution of the Gross Domestic Product (GDP) by the different sectors selected as driving forces. \\
\hline & $\begin{array}{l}\text { Fishing \& } \\
\text { tourism }\end{array}$ & $\begin{array}{l}\text { Number of investments done in the } \\
\text { sector }\end{array}$ & $\begin{array}{l}\text { Temporal and spatial number of investments done to improve the sector either fishing or tourism (in this } \\
\text { case the driving forces). }\end{array}$ \\
\hline & Fishing & Fishing boats power & $\begin{array}{l}\text { Temporal variations of the power of the fishing boats that fish in the MPA or in its boundaries or the fleet that } \\
\text { fishes close to it. }\end{array}$ \\
\hline & $\begin{array}{l}\text { Fishing \& } \\
\text { tourism }\end{array}$ & Per capita income in the area & Spatial and temporal distribution of per capita income in the area influenced by the MPA. \\
\hline & $\begin{array}{l}\text { Fishing \& } \\
\text { tourism }\end{array}$ & Per capita income of the sector & $\begin{array}{l}\text { Per capita income of the fishing and tourist sector (in this case the driving forces) in the area influenced by } \\
\text { the MPA. }\end{array}$ \\
\hline & Fishing & Fishing boats with a kind of gear & Number of fishing boats that use a determinate kind of gear. \\
\hline & Tourism & Recreational boats & $\begin{array}{l}\text { Temporal variations of the number of fishing boats that are counted or are registered in the area influenced } \\
\text { by the MPA. }\end{array}$ \\
\hline & Tourism & Spear fishing/coast & Number of people fishing with a spear by kilometres of coast influenced by the MPA. \\
\hline & Tourism & Angling/coast & Number of people counted fishing with a fishing rod along the coast influenced by the MPA. \\
\hline & Tourism & Fishing rods sold & Number of fishing rods sold per number of habitants in the area influenced by the MPA. \\
\hline & Tourism & Specialised shops & $\begin{array}{l}\text { Temporal variation in the number of specialised shop for recreational fishing established in the area within } \\
\text { the creation of the MPA. }\end{array}$ \\
\hline & Tourism & Spear guns sold/habitant & Temporal variation in the number of spear guns sold by population. \\
\hline & Tourism & Number of divers & Temporal and spatial evolution of the number of divers. \\
\hline & Tourism & Diving clubs number & Temporal and spatial evolution of the number of diving clubs in the area. \\
\hline & Tourism & Diving incomes & Temporal and spatial evolution of the incomes produced by diving activities. \\
\hline & Tourism & Diving licences number & Temporal and spatial evolution of the diving licences in the area. \\
\hline & Tourism & Influx of visitants & Temporal evolution of the visitants. \\
\hline & Tourism & Guided activities in the area & Temporal evolution of the number of the guided activities in the area. \\
\hline & Tourism & Recreational boats sold & Temporal evolution of the number of recreational boats sold in the area. \\
\hline & Tourism & Jet sky sold & Temporal evolution of the number of jet sky sold in the area. \\
\hline & Tourism & Nautical activities offered & Temporal and spatial evolution of the number of nautical activities offered in the area. \\
\hline & Tourism & Hotel accommodation offer & Temporal and spatial evolution of the hotel accommodation offer in the area. \\
\hline \multirow[t]{26}{*}{ Pressures } & Fishing & Fishing ground & Area, were the fishing is exerted. \\
\hline & Fishing & Boats fishing/day & Number of boats fishing. \\
\hline & Fishing & CPUE & Catch Per Unit Effort (CPUE). \\
\hline & Fishing & Length of net & Length of the net over a type of habitat. \\
\hline & Fishing & Number of hooks & Number of hooks over a type of habitat. \\
\hline & Fishing & Fishing time & Fishing time \\
\hline & Fishing & Total Biomass extracted & Kilograms of biomass extracted when fishing by boat and by gear. \\
\hline & Fishing & Biomass extracted by specie & Specie biomass (kilograms) extracted by boat and by gear. \\
\hline & Fishing & Individuals fished/total capture & Kilograms of individuals from the same specie fished divided by the total capture in kilograms. \\
\hline & Fishing & Number of species caught & Number of different species caught by gear. \\
\hline & Fishing & Hydrocarbons consumed & Litres of hydrocarbons consumed for fishing by boat. \\
\hline & Fishing & Organic matter thrown & Tons of organic matter thrown to the sea. \\
\hline & Fishing & Gears lost & Number of fishing gears lost. \\
\hline & Tourist & Tourist angling in coast & Number of tourist anglers along the coast (in $\mathrm{km}$ ) per day. \\
\hline & Tourist & Tourist angling in boat & Number of tourist anglers by boat along the coast (in $\mathrm{km}$ ). \\
\hline & Tourist & Spear fishers & Number of spear fishers along the coast (in km) per day. \\
\hline & Tourist & Density of recreational fishers & Temporal density of recreational fishers. \\
\hline & Tourist & Recreational fishing surface & Recreational fishing surface \\
\hline & Tourist & Recreational boats & Number of recreational boats in a day along the MPA boundaries. \\
\hline & Tourist & Boating or jet sky & Number of motor boating or jet sky in a day in the MPA or influenced area. \\
\hline & Tourist & Divers & Number of recreational divers in a day in the MPA or along its boundaries. \\
\hline & Tourist & Visitants & Number of visitants in a day in the MPA \\
\hline & Tourist & Littoral itinerary & Number of visitants in a day in a littoral itinerary or route. \\
\hline & Tourist & Hydrocarbons consumed & Hydrocarbons concentration $(\mathrm{mg} / \mathrm{l})$ consumed by boat in the closer ports. \\
\hline & Tourist & Organic matter & Quantity in tonnes $(\mathrm{Tn})$ of organic matter thrown by recreational boats \\
\hline & Tourist & Recreational boats & Number of recreational boats (fishing boats + tourism boats + whale watching $+\ldots$ ). \\
\hline \multirow[t]{7}{*}{ State } & $\begin{array}{l}\text { Fishing \& } \\
\text { tourism }\end{array}$ & Abundance & Quantity of each key specie can be found in the MPA \\
\hline & $\begin{array}{l}\text { Fishing \& } \\
\text { tourism }\end{array}$ & Biomass & Weight of each key specie that can be found in the MPA \\
\hline & $\begin{array}{l}\text { Fishing \& } \\
\text { tourism }\end{array}$ & Density & Abundance per unit area of key species are in the MPA \\
\hline & $\begin{array}{l}\text { Fishing \& } \\
\text { tourism }\end{array}$ & Size structure & Size distribution of the different key elements selected \\
\hline & $\begin{array}{l}\text { Fishing \& } \\
\text { tourism }\end{array}$ & Diversity & Assemblage structure in the MPA \\
\hline & Fishing \& & Relative Abundance & Relative abundance of key species. \\
\hline & & Richness & Number of species. \\
\hline
\end{tabular}


Table 1 (continued)

\begin{tabular}{|c|c|c|c|}
\hline Type & Sector & Indicator & Definition \\
\hline & $\begin{array}{l}\text { Fishing \& } \\
\text { tourism }\end{array}$ & & \\
\hline & $\begin{array}{l}\text { Fishing \& } \\
\text { tourism }\end{array}$ & Dominance & Relative abundance of the more abundant species \\
\hline & $\begin{array}{l}\text { Fishing \& } \\
\text { tourism }\end{array}$ & Community structure & Changes in the community structure. \\
\hline & $\begin{array}{l}\text { Fishing \& } \\
\text { tourism }\end{array}$ & Coverture & Coverture of a key specie within the boundaries of the MPA \\
\hline & $\begin{array}{l}\text { Fishing \& } \\
\text { tourism }\end{array}$ & Trophic categories & Number of trophic categories affected \\
\hline & $\begin{array}{l}\text { Fishing \& } \\
\text { tourism }\end{array}$ & Recruitment & Number of new individuals (juveniles) incorporated to a population \\
\hline & $\begin{array}{l}\text { Fishing \& } \\
\text { tourism }\end{array}$ & Occupied surface & Changes on the occupied surface \\
\hline & Tourism & Key species & Number of key species endangered by solid objects. \\
\hline & Tourism & Hydrocarbons concentration & Hydrocarbons concentration in the water column. \\
\hline & Tourism & Chemical products concentration & Chemical products concentration in the water column. \\
\hline & Tourism & Solid waste & Number of solid waste in a type of habitat. \\
\hline & Tourism & Species broken & Number of species broken by anchoring or diving. \\
\hline & Tourism & Nests & Density of bird nests. \\
\hline \multirow[t]{39}{*}{ Impacts } & Fishing & Surface affected by a gear & Total surface of a determinate kind of habitat affected by a gear. \\
\hline & Fishing & Surface affected & Total surface of a determinate kind of habitat \\
\hline & Fishing & Changes in density & Temporal and spatial changes of the quantity of key species that are in the MPA boundaries \\
\hline & $\begin{array}{l}\text { Fishing \& } \\
\text { tourism }\end{array}$ & Changes in covertures & Changes produced in the state of the key elements during the time a pressure is affecting them. \\
\hline & Fishing & Changes in community structure & Temporal and spatial changes in the community structure. \\
\hline & Fishing & Species size variation & Temporal and spatial variation of the size of the different key elements selected. \\
\hline & Fishing & Relative abundance & Temporal and spatial variations on the relative abundance of the individuals for each key species. \\
\hline & $\begin{array}{l}\text { Fishing \& } \\
\text { tourism }\end{array}$ & Changes in abundance & Temporal and spatial variations of the quantity of each key specie that can be found in the MPA \\
\hline & $\begin{array}{l}\text { Fishing \& } \\
\text { tourism }\end{array}$ & Changes in diversity & Temporal and spatial variations on the species composition structure in the MPA boundaries. \\
\hline & $\begin{array}{l}\text { Fishing \& } \\
\text { tourism }\end{array}$ & Changes in richness & Temporal and spatial variations on the number of the key species. \\
\hline & Fishing & Changes in dominance & Temporal and spatial variations on the abundance of the dominant species. \\
\hline & Fishing & Changes in sediment & Changes in sediment composition and/or quality. \\
\hline & Fishing & Species substitution & Temporal and spatial substitution of the species \\
\hline & Fishing & Families substitution & Temporal and spatial substitution of the families \\
\hline & Fishing & Changes in recruitment & Temporal and spatial variations on changes in the recruitment rate \\
\hline & Fishing & Breaking index & Temporal and spatial variations of breaking index of key species. \\
\hline & Fishing & Rugosity & Temporal changes in the rugosity of key elements \\
\hline & Fishing & Changes in habitat heterogeneity & Temporal and spatial habitat changes \\
\hline & Fishing & Changes in trophic levels & Temporal and spatial changes in trophic levels \\
\hline & Fishing & Opportunistic species & Appearance of opportunistic species. \\
\hline & Fishing & Sensitive species & Changes in sensitive species \\
\hline & Tourism & Species size & Variation of the targeted species size \\
\hline & Tourism & Species weight & Variation of the targeted species weight \\
\hline & Tourism & Mortality rate & Changes in mortality rate \\
\hline & Tourism & Captures & Temporal changes in captures \\
\hline & Tourism & Recruitment rate & Evolution in the recruitment rate \\
\hline & Tourism & Extracted biomass & Evolution of the extracted biomass \\
\hline & Tourism & Extracted biomass by specie & Evolution of the extracted biomass by specie \\
\hline & Tourism & Fragile species & Decrease of fragile species \\
\hline & Tourism & Protected species & Disappear rate of protected species \\
\hline & Tourism & Sediment & Changes in the sediment composition and/or quality \\
\hline & Tourism & Opportunistic species & Opportunistic species evolution \\
\hline & Tourism & Filter species & Evolution of filter species \\
\hline & Tourism & Anchoring & Evolution of the surface damaged by anchoring \\
\hline & Tourism & Diving activities & Evolution in the surface affected by the diving activities. \\
\hline & Tourism & Whale watching & Temporal and spatial variations in whale watching \\
\hline & Tourism & Sea mammals & Number of impacts with sea mammals \\
\hline & Tourism & Trampling & Evolution in the surface affected by the influx of visitants. \\
\hline & Tourism & Water quality & Changes in water quality \\
\hline \multirow[t]{6}{*}{ Responses } & $\begin{array}{l}\text { Fishing \& } \\
\text { tourism }\end{array}$ & Marine Protected Area & Surface of the Marine Protected Area \\
\hline & $\begin{array}{l}\text { Fishing \& } \\
\text { tourism }\end{array}$ & Integral reserve & Surface of integral reserve \\
\hline & $\begin{array}{l}\text { Fishing \& } \\
\text { tourism }\end{array}$ & Zoning surface & Surface zoned for each use \\
\hline & $\begin{array}{l}\text { Fishing \& } \\
\text { tourism }\end{array}$ & Sport fishing surface & $\%$ of the total surface of the MPA limited for sport fishing. \\
\hline & $\begin{array}{l}\text { Fishing \& } \\
\text { tourism }\end{array}$ & Diving surface & $\%$ of the total surface of the MPA limited for diving (recreational or scientific) \\
\hline & $\begin{array}{l}\text { Fishing \& } \\
\text { tourism }\end{array}$ & Budget & Total budget invested in the MPA by the governments \\
\hline
\end{tabular}


Table 1 (continued)

\begin{tabular}{|c|c|c|c|}
\hline Type & Sector & Indicator & Definition \\
\hline & $\begin{array}{l}\text { Fishing \& } \\
\text { tourism }\end{array}$ & Budget for surveillance & Temporal (annual, monthly...) budget for surveillance. \\
\hline & $\begin{array}{l}\text { Fishing \& } \\
\text { tourism }\end{array}$ & Budget for each pressure & Temporal (annual, monthly...) budget invested to research each pressure \\
\hline & $\begin{array}{l}\text { Fishing \& } \\
\text { tourism }\end{array}$ & Budget for educational programs & Budget invested in educational programs \\
\hline & $\begin{array}{l}\text { Fishing \& } \\
\text { tourism }\end{array}$ & Budget for waste programs or actions & Budget invested in waste programs or actions \\
\hline & $\begin{array}{l}\text { Fishing \& } \\
\text { tourism }\end{array}$ & Budget for anchoring points & Budget invested in anchoring points actions \\
\hline & $\begin{array}{l}\text { Fishing \& } \\
\text { tourism }\end{array}$ & $\begin{array}{l}\text { Budget for duties of management of } \\
\text { anchoring points }\end{array}$ & Budget for duties of management of anchoring points \\
\hline & $\begin{array}{l}\text { Fishing \& } \\
\text { tourism }\end{array}$ & Budget for improvement actions & Budget invested for improvement actions. \\
\hline & $\begin{array}{l}\text { Fishing \& } \\
\text { tourism }\end{array}$ & Budget for participant organisms & Budget invested for each participant organisms or stakeholder. \\
\hline & $\begin{array}{l}\text { Fishing \& } \\
\text { tourism }\end{array}$ & Participation budget & Budget invested in participation. \\
\hline & $\begin{array}{l}\text { Fishing \& } \\
\text { tourism }\end{array}$ & $\begin{array}{l}\text { Budget for research programs for each } \\
\text { pressure }\end{array}$ & Budget invested in each research program developed for the pressures acting in the MPA. \\
\hline & $\begin{array}{l}\text { Fishing \& } \\
\text { tourism }\end{array}$ & Research budget & Annual research budget. \\
\hline & $\begin{array}{l}\text { Fishing \& } \\
\text { tourism }\end{array}$ & $\begin{array}{l}\text { Budget for management actions for } \\
\text { each pressure }\end{array}$ & Budget invested for management actions for each pressure acting in the MPA. \\
\hline & $\begin{array}{l}\text { Fishing \& } \\
\text { tourism }\end{array}$ & Littoral itinerary budget & Budget invested for management and conservation of littoral itineraries. \\
\hline & $\begin{array}{l}\text { Fishing \& } \\
\text { tourism }\end{array}$ & Surveillance hours & Number of surveillance hours applied in the MPA \\
\hline & $\begin{array}{l}\text { Fishing \& } \\
\text { tourism }\end{array}$ & Anchoring surveillance & Number of surveillance hours applied in anchoring surveillance. \\
\hline & $\begin{array}{l}\text { Fishing \& } \\
\text { tourism }\end{array}$ & Licences for sport fishing & Temporal variations of the number of licences for the different kinds of sport fishing. \\
\hline & $\begin{array}{l}\text { Fishing \& } \\
\text { tourism }\end{array}$ & Denounces & Temporal variations of the number of denounces for illegal fishing or illegal diving or illegal boating. \\
\hline & $\begin{array}{l}\text { Fishing \& } \\
\text { tourism }\end{array}$ & Educational programs & Temporal variations of the number of educational programs. \\
\hline & $\begin{array}{l}\text { Fishing \& } \\
\text { tourism }\end{array}$ & Number of actions done & Temporal variations of the number of actions done to became aware of waste, recreational fishing, divers. \\
\hline & $\begin{array}{l}\text { Fishing \& } \\
\text { tourism }\end{array}$ & Anchoring points & Total number of anchoring points \\
\hline & $\begin{array}{l}\text { Fishing \& } \\
\text { tourism }\end{array}$ & Anchoring points for diving & Temporal variations of the number of anchoring points established for diving activities. \\
\hline & $\begin{array}{l}\text { Fishing \& } \\
\text { tourism }\end{array}$ & Evolution of diving in the MPA & Temporal and spatial evolution of the limitations or places for diving in the MPA or its boundaries. \\
\hline & $\begin{array}{l}\text { Fishing \& } \\
\text { tourism }\end{array}$ & Visitants surface & Terrestrial surface limited for the visitant \\
\hline & $\begin{array}{l}\text { Fishing \& } \\
\text { tourism }\end{array}$ & Littoral itineraries & Temporal and spatial evolution in the number of littoral itineraries. \\
\hline & $\begin{array}{l}\text { Fishing \& } \\
\text { tourism }\end{array}$ & Improvement actions & Temporal variations of the number of improvement actions. \\
\hline & $\begin{array}{l}\text { Fishing \& } \\
\text { tourism }\end{array}$ & People contracted & Number of people contracted in a year. \\
\hline & $\begin{array}{l}\text { Fishing \& } \\
\text { tourism }\end{array}$ & Publications & Number of publications done related to the MPA. \\
\hline & $\begin{array}{l}\text { Fishing \& } \\
\text { tourism }\end{array}$ & Research projects & Number of research projects in a year. \\
\hline & $\begin{array}{l}\text { Fishing \& } \\
\text { tourism }\end{array}$ & Meetings between the actors & Number of meetings between the actors. \\
\hline & $\begin{array}{l}\text { Fishing \& } \\
\text { tourism }\end{array}$ & People working in projects & Variations on the people working on projects. \\
\hline & $\begin{array}{l}\text { Fishing \& } \\
\text { tourism }\end{array}$ & Legislation changes & Changes in laws, normative, restrictions and/or limitations. \\
\hline
\end{tabular}

\subsection{Marine protected areas: a response}

Responses are possible at all levels in the DPSIR framework, but at the pressure and state level, measures are technically and economically hardly feasible. MPAs were being proposed widely as a tool to manage marine biodiversity and fisheries, complementarily to other management measures [75].

The selection of a site for conservation management is only one of many elements in the building of a MPA. It requires goal identification, site survey and data collection, data analysis, and data synthesis and plan formulation, all of which apply to site selection as well as all other steps in a MPA programme. Experiences and processes all over the world demonstrate that MPAs are an effective management tool.

Some key experiences can be outlined from the US Florida Keys National Marine Sanctuary, which is administered by the National Oceanic and Atmospheric Administration (NOAA) in partnership with the Florida Department of Environmental Protection (FDEP). 
In 1960 Floridians responded to early warning signs that the Keys' marine environment was fragile - that its coral reefs, seagrass beds, mangrove islands and the fish, lobsters, birds, and other creatures that lived there were not infinite. Their concern led to the creation of the world's first underwater marine park, the John Pennekamp Coral Reef State Park. In 1990 Congress designated the Florida Keys National Marine Sanctuary. It encompasses the goals of balancing the long-term health of the ecosystem with the economy it supports [76]. In Australia examples like the Great Barrier and Ningaloo Marine Parks can be found. Scattered over a distance of 2300 kilometres, from the middle of Australia's eastern coast northwards to Papua New Guinea, lies the Great Barrier Reef. Not really a continuous barrier but a collection of about 3400 separates coral reefs, shoals and other formations, it is the largest system of coral reefs in the world and one of the main examples of protection, conservation and management. Australia had already taken action to protect coral reefs when it established the Great Barrier Reef Marine Park. The Marine Park is a multiple-use management approach which aims to achieve reasonable use consistent with conservation. The Great Barrier Reef Marine Park, approved in 1975 anticipated the 1981 World Conservation Strategy and it may be unique in providing specifically for conservation and reasonable use, or sustainable development of a large area of recognised conservational significance $[77,78]$. Another example in this region is the Ningaloo Marine Park in Australia that is managed to conserve a unique environment for the enjoyment of visitors. This area was in 1987 under the National Parks and Wildlife Conservation Act 1975 (NPWC Act). Its management plan sets out the main objectives for the park management, as conservation, recreation, science and education. This Park is protected to allow sustainable recreation for current and future generations. In the Mediterranean region MPAs have also been established to protect marine biodiversity and restocking commercial species, exhibiting a high heterogeneity in terms of zoning, management and results [35].

As these examples show the MPAs were chosen as tools to mitigate the impacts caused by different socioeconomic activities on marine resources, at least in some very representative areas. For this reason, MPAs and their related management activities should be considered, in this conceptual framework, as responses (e.g. this can be measured through the evolution of the budget and the number of surveillance hours as a management response indicator. Fig. 8). They were divided in two different stages: plan the uses and activities allowed or forbidden in the area of the reserve and management of the different activities planned to enhance different programs developed in the reserve.

\subsection{DPSIR framework to select indicators}

We linked the components of the DPSIR framework through cause-effect connections. Once these links were obtained, we defined parameters that could be measured to assess the protection effect for each of the components of the framework. In this way we obtained variables for the driving forces, pressures, states, impacts and responses for both, fishing and tourism sectors. Finally 149 variables were defined and classified within the DPSIR framework (Table 1). Here we present variables that have been defined for a general conceptual model for MPAs and that could be used as potential indicators, although they have to be adapted to each particular case study.

\section{Discussion}

A general conceptual framework using the DPSIR methodology to analyse the socioeconomic issues, environmental changes and policy responses of MPAs, was developed. This framework was developed through a participation process which involved an expert panel but must be used by managers and evaluated by the stakeholders implicated in the MPA. From this conceptual framework a set of variables for each DPSIR component were defined. These variables will be evaluated as indicators through criteria by a participation process which also involves managers. Also this framework helped us to analyse and find gaps on the management of an MPA. This general framework seems to be appropriated for the evaluation of the problems developed in an MPA.

To develop the conceptual framework, we used the DPSIR framework [8], among many other methodologies because it demonstrates and illustrates the complexity of linkages between the causes and impacts to managers, politicians, resource users and scientists. DPSIR also allows a holistic and multi-dimensional view of causal relationships. The DPSIR framework is an extended version of the Pressure-State-Response (PSR) approach, that is based on the idea that anthropogenic activities impact the environment and that adverse environmental impacts drive humans to control the pressures. It introduces two new concepts: human welfare and environmental quality and societal behaviour and economic pressures affecting the environment, incorporating them as "Driving Forces" and "Impacts". This methodology also embraces the process of indicator linkages of environmental functions. Under DPSIR, environmental problems and solutions are simplified into variables that stress the cause-effect relationships between human activities that exert pressures on the environment, the condition of the environment and society's response to the condition [14]. Other systematic conservation planning tools, like Marxan [79] and MarZone [80], consider biodiversity conservation and socioeconomic interests ad hoc to design networks of marine protected areas. These tools incorporate data to model predictions about the results of the management. The conceptual framework resulting from DPSIR methodology was proposed as a first step to define the condition of certain MPAs, enabling the use of further and more accurate tools. The incorporation of different approaches will increase the efficiency of designing marine protected areas that will satisfy biodiversity conservation goals and will be socioeconomically viable.

The conceptual framework can be applied to any case study and it should be used as a system guide for MPA planners and managers. For a right application of the conceptual framework to develop an ecosystem based approach management, species, habitats, the whole ecosystem, diverse and potentially conflicting uses, thus a diversity of stakeholders, for a certain case study must be contemplated. In this process, various stakeholders might have different conceptual frameworks to be, to the extent possible, reconciled and accommodated in a common conceptual framework. The exact composition of the framework can change in response to the concerned person and/or institution necessities. Thus, if this framework is applied and there exists local legislation, it must be considered. Diagrams represented here are a general example, applying them must be done with the legislation and specific characteristics of each MPAs. Also for each application there will be different problems, uses, necessities and stakeholders that must be considered when defining the DPSIR components and making the cause-effect diagrams.

The relationship between marine science and marine policy has historically been challenging, with examples from fisheries, water quality, whaling, and marine conservation readily available [81]. The challenging relationship has often been attributed to the form of interaction between marine scientists and those involved in policy-making [82]. It can also be argued that the MPA definition issue is a factor. Scientists and conservationists who focus only on MPAs as no-take reserves set up a counterpoint "game" with fishery interests who can spend energy resisting loss of fishing areas rather than investing research and resources into developing verifiability indicators and management measures for ecologically 
sustainable fisheries. This well known divorce between science and management is reflected in, that most of science research does not respond to management necessities. This lack of response to MPAs management objectives is focused on gaps on research in determinate fields such as: temporal data for states, and non-existence of data concerning responses and driving forces. The adoption of an objective-based management system for the marine environment and application of conceptual frameworks will require some adaptation and reconciliation by managers, scientists and stakeholders, as has been happening in several parts of the world for 10 or more years [83]. Social approaches and negotiation processes, and science as a trans-cultural and testable knowledge can play a role in this framework. This methodology will make management simpler to understand and will make easiest to spread it to stakeholders.

\section{Conclusions}

The DPSIR scheme of indicators is a flexible framework that can be adapted to the necessities of specific programmes to identify the different actors and processes affecting the MPA and surrounding areas. It allows a better understanding of the effects of management actions on the different system components (e.g. the fisheries, the socioeconomics), and hence is more suitable in the identification and analysis of indicators. Its structure can be used to select indicators as is being done in the implementation of e.g. European Water Framework Directive [15-17]. Moreover it can be a very effective tool to organize participation processes to better involve stakeholders, managers and scientists.

\section{Acknowledgments}

This work has been carried out with financial support from the Commission of the European Community, specific RTD programme "Specific Support to Policies", SSP-2003-006539 “European Marine Protected Areas as Tools for Fisheries Management and Conservation (EMPAFISH)". It does not necessarily reflect its views and in no way anticipates the Commission's future policy in this area. We thank two anonymous referees for their helpful suggestions and every member of the project who has directly been involved in this document, for their patience and their advice. The authors are very grateful to Pedro Cartagena Rocamora for his helpful advice on DPSIR methodology.

\section{References}

[1] Kelleher G, Bleakly C, Wells S. In: A global representative system of marine protected areas. The great barrier reef marine park authority, the world bank and the world conservation union (IUCN). Washington, DC, USA: Environment Department, The World Bank; 1995.

[2] Wood LJ, Fish L, Laughren J, Pauly D. Assessing progress towards global marine protection targets: shortfalls in information and action. Fisheries centre working paper \#2007-03. Vancouver, B.C., Canada: The University of British Columbia; 2007.

[3] IUCN-The World Conservation Union. Resolution 17.38 of the 17th general assembly of the IUCN. Switzerland and Cambridge, UK: Gland; 1987.

[4] Kelleher G, Kenchington R. Guidelines for establishing marine protected areas. Gland, Switzerland: International Union for Conservation of Nature and Natural Resources; 1992.

[5] Lubchenco J, Palumbi SR, Gaines SD, Andelman S. Plugging a hole in the ocean: the emerging science of marine reserves. Ecological Applications 2003;13(Suppl. 1):S3-7.

[6] Kelleher G. Guidelines for marine protected areas. Gland, Switzerland and Cambridge, UK: IUCN; 1999.

[7] OECD(Organisation for Economic Co-operation and Development). Environmental indicators: a preliminary set. Paris: OECD; 1991

[8] OECD(Organisation for Economic Co-operation and Development). Environmental indicators: OECD core set. Paris: OECD; 1994.

[9] EEA (European Environment Agency). Environmental indicators: typology and overview. Technical report No 25. Copenhagen, Denmark: European Environment Agency; 1999.
[10] EEA (European Environment Agency). State and pressures of the marine and coastal Mediterranean environment. Environmental assessment series. Copenhagen, Denmark: European Environment Agency; 1999.

[11] DEFRA. A biodiversity strategy for England. Measuring progress: baseline assessment. England: England Biodiversity Group Working with the GRAIN of Nature; 2003.

[12] Boyd H, Charles A. Creating community-based indicators to monitor sustainability of local fisheries. Ocean \& Coastal Management 2006;49(5-6): 237-58.

[13] Pomeroy RS, Parks JE, Watson LM. How is your MPA doing? A guidebook of natural and social indicators for evaluating marine protected area management effectiveness. Gland, Switerland and Cambridge, UK: IUCN; 2004. p. 216

[14] Mangi SC, Roberts CM, Rodwell LD. Reef fisheries management in Kenya: preliminary approach using the driver-pressure-state-impacts-response (DPSIR) scheme of indicators. Ocean \& Coastal Management 2007;50:463-80.

[15] La Jeunesse I, Rounsevell M, Vanclooster M. Delivering a decision support system tool to a river contract: a way to implement the participatory approach principle at the catchment scale? Physics and Chemistry of the Earth 2003;28:547-55.

[16] Mysiak J, Giupponi C, Rosato P. Towards the development of a decision support system for water resource management. Environmental Modelling and Software 2005;20(2):203-14.

[17] Borja A, Josefson AB, Miles A, Muxika I, Olsgard F, Phillips G, et al. An approach to the intercalibration of benthic ecological status assessment in the North Atlantic ecoregion, according to the European water framework directive. Marine Pollution Bulletin 2007;55:42-52.

[18] Cooley B, Goddard C, Hancock P, O'Connell E, McCoy M. Pensacola bay ecosystem management plan. Environmental indicators system. Pensacola, Florida, USA: Florida Department of Environmental Protection; 1996.

[19] Chesapeake Bay Program/USEPA. Environmental outcome-based management: using environmental goals and measures in the Chesapeake bay program. EPA 903-R-00-016. CBP/TRS 248/00. Chesapeake Bay Program. Annapolis, USA: United States Environmental Protection Agency; 1999.

[20] Casazza G, Silvestri C, Spada E, Melley A. Coastal environment in Italy: preliminary approach using the "DPSIR Scheme" of indicators. In: Gomes FV, editor. Sixth international symposium proceedings: a multi-disciplinary symposium on coastal zone research, vol. 2. Porto, Portugal, Littoral: Management and Planning; 2002. p. 541-9.

[21] Casazza G, Cecilia S, Emanuela S. The use of bio-indicators for quality assessments of the marine environment: examples from the Mediterranean sea. Journal of Coastal Research 2002;8:147-56.

[22] Elliott M. The role of the DPSIR approach and conceptual models in marine environmental management: an example for offshore wind power. Marine Pollution Bulletin 2002;44:iii-vii.

[23] Jorge MR, Lourenço N, Machado CR, Rodrigues L. Measuring monitoring and managing sustainability in Indian coastal areas: The socioeconomic dimension. In: Veloso-Gomes F, Taveira-Pinto F, Neves L, editors. Proceeding of Littoral. The changing coast. Porto, Portugal: EUROCOAST/EUCC; 2002. p. 237-247.

[24] Silva MC, Rodrigues AC. Environmental indicators as management tools of estuaries. Methodology and the case of the Tejo estuary. In: Veloso-Gomes F, Taveira-Pinto F, Neves L, editors. Littoral 2002, the changing coast. Porto, Portugal: European Coastal Zone Association for Science and Technology (EUROCOAST)-Portugal Association/EUCC - The Coastal Union; 2002. p. 199-210.

[25] Nunneri C, Hoffmann J. Integrated coastal zone management and river basin management and application of GIS for the river Elbe management (Germany). In: Proceedings of fifth international symposium on GIS and computer cartography for coastal zone management. Genoa, Italy: GISIG/ICOOPS; 2003. p. 1-11.

[26] Picollo A, Albertelli G, Bava S, Cappo S. The role of geographic information systems (GIS) and of DPSIR model in Ligurian coastal zone management. In: Proceedings of fifth international symposium on GIS and computer cartography for coastal zone management. Genoa, Italy: GISIG/ICOOPS; 2003. p. 1-5.

[27] IUCN (International Union for Conservation of Nature). Guidelines for protected area management categories. Gland, Switzerland and Cambridge, UK: IUCN; 1994.

[28] CBD (Convention on Biological Diversity). Draft global outcome-oriented targets for the programme of work on marine and coastal biological diversity. UNEP/CBD/SBSTTA/10/8/Add; 2004.

[29] Willis TJ, Millar RB, Babcock RC, Tolimieri N. Burdens of evidence and the benefits of marine reserves: putting descartes before des horse? Environmental Conservation 2003;30(2):97-103.

[30] Murawski SA, Brown R, Lai H-L, Rago PJ, Hendrickson L. Large-scale closed areas as a fishery-management tool in temperate marine systems: the Georges bank experience. Bulletin of Marine Science 2000;66(3):775-798.

[31] Kaiser MJ. Are marine protected areas a red herring or fisheries panacea? Canadian Journal of Fisheries and Aquatic Sciences 2005;62(5):1194-1199.

[32] Kaiser MJ, Blyth-Skyrme RE, Hart PJB, Edwards-Jones G, Palmer D. Evidence for greater reproductive output per unit area in areas protected from fishing. Canadian Journal of Fisheries and Aquatic Sciences 2007;64:1284-1289.

[33] Ramos TB, Caeiro S, Melo JJ. Environmental indicators frameworks to design and assess environmental monitoring programs. Impact Assessment and Project Appraisal 2004;22(1):47-62.

[34] Goñi R. Ecosystem effects of marine fisheries: an overview. Ocean and Coasta Management 1998;40:37-64. 
[35] Francour P, Harmelin J-G, Pollard D, Sartoretto S. A review of marine protected areas in the northwestern Mediterranean region: sitting, usage, zonation and management. Aquatic Conservation: Marine and Freshwater Ecosystems 2001;11:155-188

[36] Crawford BR, Siahainenia A, Rotinsulu C, Sukmara A. Compliance and enforcement of community-based coastal resource management regulations in North Sulawesi, Indonesia. Coastal Management 2004;32(1):39-50.

[37] McIntyre S, Hobbs R. A framework for conceptualizing human effects on landscapes and its relevance to management and research models. Conservation Biology Dec 1999;13(6):1282-1292.

[38] Finley BL, Iannuzzi TJ, Wilson ND, Kinnell JC, Craven VA, Lemeshow S, et al. The Passaic river creel/angler survey: expert panel review, findings, and recommendations. Human and Ecological Risk Assessment 2003;9(3): 829-855.

[39] Tudela S, Kai Kai A, Maynou F, El Andalosi M, Guglielmi P. Driftnet fishing and biodiversity conservation: the case study of the large-scale Morocan driftne fleet operating in the Alboran Sea (SW Mediterranean). Biological Conservation 2005;121:65-78.

[40] Koslow JA. Managing nonrandomly varying fisheries. Canadian Journal of Fisheries and Aquatic Sciences 1989:46:1302-1308.

[41] Bohnsack JA. Protection of grouper spawning aggregations. Coastal resource division contribution: CRD-88/89-06. Miami, Florida: Southeast Fisheries Science Center; 1989.

[42] Gislason H. Ecosystem effects of fishing activities in the north sea. Marine Pollution Bulletin 1994;68:520-527.

[43] Sluka RD, Sullivan KM. The influence of spear fishing on species composition and size of groupers on match reefs in the upper Florida keys. Fishery Bulletin 1998;96:388-392.

[44] Sánchez F, Olaso I. Effects of fisheries on the Cantabrian sea shelf ecosystem. Ecological Modelling 2004;172:151-174.

[45] Garthe S, Camphuysen K, Furness R. Amounts of discards by commercial fisheries and their significance as food for seabirds in the north sea. Marine Ecology Progress Series 1996;136:1-11.

[46] Munro JL, Parrish JD, Talbot FH. The biological effect of intensive fishing upon reef fish communities. In: Salvat B, editor. Human impacts on coral reefs; facts and recommendations. French Polynesia: Antenne Musseum EPHE; 1987. p. 41-49.

[47] Eno NC, MacDonalds DS, Amos SC. A study on the effects of fish (crustacea mollusc) traps on benthic habitats and species. Report to European Commision Directorate General XIV; 1996. Studies contract: 94/076.

[48] MacDonalds DS, Little M, Eno NC, Hiscock K. Towards assessing the sensitivity of benthic species and in relation to fishing activities. Aquatic Conservation: Marine and Freshwater Ecosystems 1996;6:257-268.

[49] Chan EH, Liew HC, Mazlan AG. The incidental capture of sea turtles in fishing gear in Terengganu, Malaysia. Biological Conservation 1988;43:1-7.

[50] Tasker ML, Camphuysen CJ, Cooper J, Garthe S, Monterecchi WA, Blaber SJM. The impacts of fishing on marine birds. ICES Journal of Marine Science 2000;57:531-547.

[51] Hall CM. Trends in ocean and coastal tourism: the end of the last frontier? Ocean and Coastal Management 2001;44:601-618.

[52] Santana A. Antropología del turismo, ¿nuevas hordas, viejas culturas?. Barcelona, Spain: Ariel; 1997.

[53] Coll J, García-Rubies A, Moranta J, Stefanni S, Morales-Nin A. Efectes de la prohibició de la pesca esportiva sobre l'estructura poblacional de l'anfós (Epinephelus marginatus Lowe, 1834. Pisces, Serranidae) en el Parc Naciona de Cabrera. Bolleti Societat d'Historia Natural de les Balears 1999;42:125-138.

[54] Murray SN, Denis TG, Kido JS, Smith JR. Human visitation and the frequency and potential effects of collecting on rocky intertidal populations in southern California marine reserves reports, vol. 40. California, USA: CalCOFI 1999. p. 100-6.

[55] Policansky D. Catch-and-release recreational fishing: a historical perspective. In: Pitcher TJ, Hollingworth CE, editors. Recreational fisheries: ecological, economical and social evaluation. Oxford, UK: Blackwell Science; 2002. p. 74-94.

[56] Bell JD. Effects of depth and marine reserve fishing restrictions on the structure of a rocky reef fish assemblage in the north western Mediterranean sea. Journal of Applied Ecology 1983;20:357-369.

[57] García-Rubies A, Zabala M. Effects of total fishing prohibition on the rocha fish assemblages of Medes islands marine reserve (NW Mediterranean). Scientia Marina 1990;54(4):317-328.

[58] Moranta J, Reviriego B, Coll J. Contribución al conocimiento de la estructura de la comunidad íctica asociada a los fondos rocosos litorales de las islas del Toro y d'Es Malgrat (suroeste de Mallorca, islas Baleares). Publicaciones Especiales Instituto Español de Oceanografía 1997;23:143-152.

[59] Reñones O, Moranta J, Coll J, Morales-Nin B. Rocky bottom fish communities of Cabrera Archipelago national park (Mallorca, western Mediterranean). Scientia Marina 1997;1997(61):495-506.
[60] Harmelin JG, Marinopoulos J. Recensement de la population de corbs (Sciaena umbra Linneaus 1758: Pisces) du Parc national de Port-Cros (Méditerránée, France) par inventaires visuels, vol. 15. France: Science Report Port-Cros National Park; 1993. p. 265-75

[61] Zabala M, García-Rubies A, Louisy P, Sala E. Spawning bahaviour of the Mediterranean dusky grouper Epinephelus marginatus (Lowe, 1834) (pisces, serranidae) in the Medes islands marine reserve (NW Mediterranean, Spain). Sciencia Marina 1997;61(1):65-77.

[62] Jouvenel J-Y, Pollard DA. Some effects of marine reserve protection on the population structure of two spearfishing target-fish species, Dicentrarchus labrax (Moronidae) and Sparus aurata (Sparidae), in shallow inshore waters, along a rocky coast in the northern Mediterranean Sea. Aquatic Conservation: Marine and Freshwater Ecosystems 2001:11:1-9.

[63] Barker NHL, Roberts CM. Scuba diver behaviour and the management of diving impacts on coral reefs. Biological Conservation 2004;120:481-489.

[64] Rouphael T, Inglis G. The effects of qualified recreational SCUBA divers on cora reefs. CRC Reef Research Centre Technical report no. 4, Townsville, Australia; 1995.

[65] Harriott VJ, Davis D, Banks SA. Recreational diving and its impact in marine protected areas in eastern Australia. Ambio 1997:26:173-179.

[66] Sala E, Garrabou J, Zabala M. Effects of diver frequentation on Mediterranean sublitoral populations of the bryozoan Pentapora fascialis. Marine Biology 1996; $126: 451-459$.

[67] Milazzo M, Badalamenti F, Vega-Fernandez T, Chemello R. Effects of fish feeding by snorkellers on the density and size distribution of fishes in a Mediterranean marine protected area. Marine Biology 146:1213-22.

[68] Schiel DR, Taylor DI. Effects of trampling on a rocky intertidal algal assemblage in southern New Zealand. Journal of Experimental Marine Biology and Ecology 1999;235:213-235.

[69] Milazzo M, Chemello R, Badalamenti F, Riggio S. Short-term effect of human trampling on the upper infralittoral macroalgae of Ustica Island MPA (western Mediterranean, Italy). Journal of the Marine Biological Association UK 2002;82:745-748.

[70] Milazzo M, Riggio S, Badalamenti F, Chemello R. Patterns of algal recovery and small-scale effects of canopy removal as a result of human trampling on a Mediterranean rocky shallow community. Biological Conservation 2004; 117:191-202.

[71] Mazón T, Aledo A, editors. Turismo Residencial y Cambio Social. Nuevas perspectivas teóricas y empíricas. Alicante, Spain: CAM, FRAX and Alicante University. Agua Clara S.L.; 2005. p. 565.

[72] Burak S, Dogan E, Gazioglub C. Impact of urbanization and tourism on coastal environment. Ocean \& Coastal Management 2004;47:515-527.

[73] Milazzo M, Badalamenti F, Ceccherelli G, Chemello R. Boat anchoring on Posidonia oceanica beds in a marine protected area (Italy, western Mediterranean): effect of anchor types in different anchoring stages. Journal of Experimental Marine Biology and Ecology 2004;299:51-62.

[74] Garcia-Charton JA, Bayle-Sempere JT, Sánchez Lizaso JL, Chiesa P, Llaurado F, Perez C, et al. Respuesta de la pradera de Posidonia oceanica y su ictiofaua sociada al anclaje de embarcaciones en el Parque Natural de Port-Cros (Francia). Publicaciones Especiales Instituto Español de Oceanografía 1993;11:423-430.

[75] Kellegher G. A global representative system of marine protected areas. Ocean \& Coastal Management 1996;32(2):123-126.

[76] Bhat MG. Application of non-market valuation to the Florida keys marine reserve management. Journal of Environmental Management 2003:67:315-325.

[77] Brodie J. Management of the great barrier reef as a large marine ecosystem. In: Sherman K, Tang Q editors. Large marine ecosystems of the pacific rim. Malden: Blackwell Science; 1999. p. 428-437.

[78] Brodie J. Keeping the wolf from the door: managing land-based threats to the great barrier reef (GBR). In: Proceedings of the ninth international coral reef symposium, Bali; 2001.

[79] Possingham HP, Ball IR, Andelman S. Mathematical methods for identifying representative reserve networks. In: Ferson S, Burgman M, editors. Quantitative methods for conservation biology. New York: Springer-Verlag; 2000. p. 291-305.

[80] Watts M, Klein C, Ball I, Possingham H. MarZone: protected area design using spatially explicit annealing. Brisbane: University of Queensland; 2006.

[81] Duda AM, Sherman K. A new imperative for improving management of large marine ecosystems. Ocean \& Coastal Management 2002:42:797-833.

[82] Fletcher S. Converting science to policy through stakeholder involvement: an analysis of the European marine strategy directive. Marine Pollution Bulletin 2007:54:1881-1886.

[83] Andrews G. Mafia island marine park, Tanzania: implications of applying a marine park paradigm in a developing country. ITMEMS Proceedings 1998:267-279.

[84] Ramos AA. La Reserva Marina de la Isla Plana o Nueva Tabarca (Alicante). Publicaciones de la Universidad de Alicante - Ayuntamiento de Alicante; 1985. 